\begin{abstract}
References
1. Evonich RF, Stephens JC, Merhi W, Dukkipati S, Tepe N, Shannon F, et al. The role of temporary biventricular pacing in the cardiac surgical patient with severely reduced left ventricular systolic function. J Thorac Cardiovasc Surg. 2008;136:915-21.

2. Flynn MJ, McComb JM, Dark JH. Temporary left ventricular pacing improve haemodynamic performance in patients requiring epicardial pacing post cardiac surgery. Eur J Cardiothorac Surg. 2005; 28:250-3.
\end{abstract}

doi:10.1016/j.jtcvs.2009.03.056

\section{PERCUTANEOUS AORTIC VALVE IMPLANTATION: WHAT DOES OVERSIZING MEAN?} To the Editor:

We read with interest the recent article by Litzler and colleagues ${ }^{1}$ in the Journal of Thoracic and Cardiovascular Surgery. The authors reported their first case of emergency surgical aortic valve replacement for severe acute aortic regurgitation after retrograde transfemoral Cribier-Edwards valve implantation.

We would like to comment on this instructive case report and ask for some clarifications:

When valved stent implantation is planned in a patient, accurate preprocedural determination of the aortic annulus size is of crucial importance. A prosthesis-aortic annulus mismatch may be responsible for valve migration or severe paravalvular leak if the chosen prosthesis is too small and for coronary obstruction or leaflet distortion if it is too large. ${ }^{2}$

The incidence of paravalvular leak has been shown to be dramatically high in previous studies. ${ }^{3,4}$ To reduce the incidence and severity of paravalvular leak, the oversizing technique (ie, the choice of a prosthesis size at least $2 \mathrm{~mm}$ more than that of the aortic annulus diameter as determined by transthoracic echocardiography [TTE]) has been proposed and proved to be effective. ${ }^{4}$

Nevertheless, several previous studies have shown that measurement of the aortic annulus diameter by TTE is inaccurate when compared with surgical sizing. ${ }^{5}$ TTE tends to underesti-

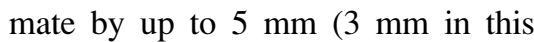
case report) the size of the aortic annulus. In the present case, the chosen size of the implanted valve was $23 \mathrm{~mm}$. The latter was supposed to be oversized based on the TTE measurements. The surgically implanted valve was also $23 \mathrm{~mm}$ based on the surgical measurements. Despite "oversizing" in this reported percutaneous valve implantation, severe paravalvular leak occurred, which means, in a sense, that this strategy has not solved this major problem at the present time.

We would like to ask the authors a few questions:

- What does "oversizing" mean for them in the choice of the implantable valve ? Is oversizing based on the TTE measurements of the aortic annulus diameter or is it based on the "true", aortic annulus diameter if the latter could be measured?

- Do they still rely on TTE for determination of the aortic annulus diameter or have they changed their imaging technique?

- Have they changed the magnitude of oversizing, based on this reported experience?

- If so, how effective is their new approach regarding the occurrence of paravalvular leak?

Optimal sizing of valved stents remains a critical issue with many implications on the post-procedural course. The readers of the Journal would greatly appreciate the answers to these "practical" questions from one of the most experienced teams in interventional aortic valve therapy.

$$
\begin{array}{r}
\text { Rachid Zegdi, } M D, P h D^{a, b} \\
\text { Paul Achouh, } M D, P h D^{b} \\
\text { Didier Blanchard, } M D^{c} \\
\text { Antoine Lafont, MD, } P h D^{a, c} \\
\text { Jean-Noël Fabiani, } M D^{a, b} \\
{ }^{a} \text { Université René Descartes } \\
\text { Paris } V, \text { France } \\
{ }^{b} \text { Assistance Publique-Hôpitaux de } \\
\text { Paris, AP-HP } \\
\text { Service de Chirurgie } \\
\text { Cardiovasculaire }
\end{array}
$$

Hôpital Européen Georges Pompidou

Paris, France

${ }^{c}$ Assistance Publique-Hôpitaux de

Paris, AP-HP

Service de Cardiologie

Hôpital Européen Georges Pompidou

Paris, France

\section{References}

1. Litzler P-Y, Cribier A, Zajarias A, Comte D, Eltchaninoff $\mathrm{H}$, Tron C, et al. Surgical aortic valve replacement after percutaneous aortic valve implantation: what have we learned? J Thorac Cardiovasc Surg. 2008;136:697-701.

2. Zegdi R, Ciobotaru V, Noghin M, Sleilaty G, Lafont A, Latremouille $\mathrm{C}$, et al. Is it reasonable to treat all calcified aortic valves with a valved stent? Results from a human anatomic study. J Am Coll Cardiol. 2008;51:579-84.

3. Webb JG, Chandavimol M, Thompson CR, Ricci DR, Carere RG, Munt BI, et al. Percutaneous aortic valve implantation retrograde from the femoral artery. Circulation. 2006;113:842-50.

4. Cribier A, Eltchaninoff $\mathrm{H}$, Tron $\mathrm{C}$, Bauer $\mathrm{F}$, Agatiello C, Nercolini D, et al. Treatment of calcific aortic stenosis with the percutaneous heart valve. Mid-term follow-up from the initial feasibility studies: the French experience. J Am Coll Cardiol. 2006; 47:1214-23.

5. Mackay A, Been M, Rodrigues E, Murchison J, De Bono DP. Preoperative prediction of prosthesis size using cross sectional echocardiography in patients requiring aortic valve replacement. Br Heart J. 1985;53:507-9

doi:10.1016/j.jtcvs.2008.11.072

\section{PROGNOSTIC SIGNIFICANCE OF VISCERAL PLEURAL INVASION AND TUMOR SIZE IN NON-SMALL CELL LUNG CANCER}

\section{To the Editor:}

We read with great interest the article by Shimizu and colleagues ${ }^{1}$ published in the July 2005 issue of the Journal. They found that visceral pleural invasion (VPI) is a significant poor prognostic factor of non-small cell lung cancer (NSCLC), regardless of N status. Stage I NSCLC has been subdivided into IA (T1NOM0) and IB (T2NOM0) based on tumor size ( $3 \mathrm{~cm}$ as a cutoff value) and non-size-based T2 descriptors (including VPI, hilar atelectasis, and obstructive pneumonitis). ${ }^{2}$ Although a poor prognostic effect of VPI has generally been reported, its prognostic value for survival has remained controversial. ${ }^{3,4}$ 